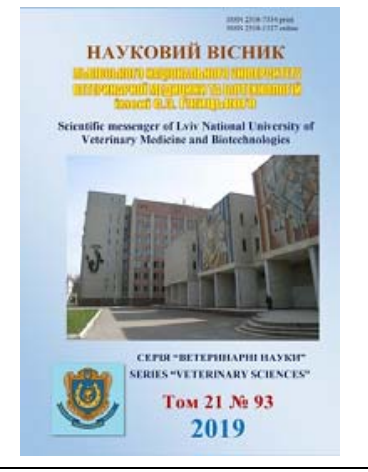

\author{
Науковий вісник Дьвівського національного університету \\ ветеринарної медицини та біотехнологій імені С.З. Гжицького. \\ Серія: Ветеринарні науки \\ Scientific Messenger of Lviv National University \\ of Veterinary Medicine and Biotechnologies. \\ Series: Veterinary sciences
}

\title{
The morphological changes in the blood of the predatory fish species with eustrongylidosis
}

\section{S. Goncharov}

National University of Life and Environmental Sciences of Ukraine, Kyiv, Ukraine

Article info

Received 17.01.2019

Received in revised form 26.02.2019

Accepted 27.02.2019

National University of Life and Environmental Sciences of Ukraine, str. Polkovnyka Potekhina, 16, Kyiv, 03041, Ukraine.

Tel.:+38-097-902-26-85 E-mail: sergeyvet85@ukr.net
Goncharov, S. (2019). The morphological changes in the blood of the predatory fish species with eustrongylidosis. Scientific Messenger of Lviv National University of Veterinary Medicine and Biotechnologies. Series: Veterinary sciences, 21(93), 15-20. doi: 10.32718/nvlvet9303

The article presents the results of the research concerning the morphological changes in the blood of the predatory fish species (perch, pike and zander) caused by nematodical parasitic disease - eustrongylidosis. The research has been conducted in 2014-2018. It has been found that in the blood of perch with eustrongylidosis the hemoglobin and the red-blood-cell count decreased by 6.87 and 42.11 respectively, the white-blood-cell count increased by 8.95\%; the basophils and pseudobasophils count - by $129.17 \%$; the eosinophils and pseudoeosinophils count - by 131\%; the number of band and segmented neutrophils increased by 27.92 and $37.5 \%$ respectively; the young neutrophils were not registered; the number of monocytes - by $16.34 \%$; the lymphocyte count reduced by $3.27 \%$ in contrast with a fish that were not sick with the disease. The significant morphological changes in the blood of pikes with eustrongylidosis were also observed. Thus, the hemoglobin concentration, the number of red blood cells and lymphocytes decreased by 11.02, 26.32 and 3.16\% respectively. The total leukocytes count increased by $22.02 \%$; the basophils and pseudobasophils count - by 114\%; the eosinophils and pseudoiesinophils count - by 95.83\%; the number of band and segmented neutrophils increased by 1.71 and $46.72 \%$ respectively; a reduction of the young neutrophil granulocytes amount to $26 \%$ was noted; the number of monocytes of the blood increased by $25.83 \%$ in contrast with pikes that were not affected by the eustrongylidosis. A reduction of the red-bloodcell and lymphocytes amount, as well as hemoglobin concentration - to 30.05, $4.4 \mathrm{ma} 6.3 \%$ respectively was observed in hematological screening of the blood of zanders. The amount of leukocytes in the blood of infested fish increased by 10.6\%; the basophils and pseudobasophils count - by 69.23\%; the eosinophils and pseudoeosinophils count - by $116.67 \%$; the number of band and segmented neutrophils increased by 15.58 and $23.27 \%$ respectively; the elevation of the number of young neutrophils to $5.75 \%$ was registered; the number of monocytes increased by $17.46 \%$ in contrast with zanders that were not infested.

Key words: hematological screening, blood morphology, eustrongylidosis, hemoglobin, red blood cells, white blood cells, prevalence of infestation, Dnipro-Bug estuary, Mykolayiv and Odesa regions.

\section{Морфологічні зміни крові хижих видів риб за еустронгілідозу}

\author{
С.Л. Гончаров
}

Національний університет біоресурсів та природокористування Украӥни, м. Київ, Украӥна

\footnotetext{
У статті наведено результати дослідження морфологічних змін у крові хижих видів риб: окуня, шуки та судака за нематодозного паразитарного захворювання - еустронгілідозу. Дослідження проведено у період 2014-2018 рр. Виявлено, що за еустронгілідозу в крові окуня вміст гемоглобіну та кількість еритроцитів зменшується на 6,87 та 42,11 відповідно, кількість лейкоцитів зростала на 8,95\%; базофілів та псевдобазофілів на 129,17\%; еозинофілів та псевдоеозинофілів на 131\%; кількість паличко- та сегментоядерних нейтрофілів збільшувалась на 27,92 та 37,5\% відповідно, юних нейтрофілів не реєстрували; моноцитів - на 16,34\%; кількість лімфоцитів крові зменшувалась на 3,27\% порівняно з рибами, щьо не були хворі на зазначене захворювання. У крові щук також спостерігали значні зміни морфологічних показників крові за еустронгілідозу. Так, вміст гемоглобіну, кількість
} 
еритрочитів та лімфоччитів зменшувалась на 11,02, 26,32 і 3,16\% відповідно. Загальна кількість лейкоичтів збільшувалась на 22,02\%; базофілів та псевдобазофілів на 114\%; еозинофілів та псевдоеозинофілів на 95,83\%; кількість паличко- та сегментоядерних нейтрофілів збільшувалась на 1,71 та 46,72\% відповідно; відмічали зменшення кількості юних нейтрофільних гранулоцитів на 26\%; кількість моноцитів крові збільшувалась на 25,83\% порівняно із щуками, які не були уражені збудником еустронгілідозу. При проведенні гематологічних досліджень крові судаків було відмічено зменшення кількості еритрочитів та лімфоцитів крові, а також вмісту гемоглобіну на - 30,05, 4,4 та 6,3\% відповідно. Кількість лейкоцитів збільшувалась в крові інвазованих риб на 10,6\%; базофілів та псевдобазофілів на 69,23\%; еозинофілів та псевдоеозинофілів на 116,67\%; кількість паличко- та сегментоядерних нейтрофілів збільшувалась на 15,58 та 23,27\% відповідно; реєстрували збільшення кількості юних нейтрофілів крові на 5,75\%; кількість моноцитів збільщувалась порівняно з судаками, щзо були вільними від цієї інвазї, на 17,46\%.

Ключові слова: гематологічні дослідження, морфологія крові, еустронгілідоз, гемоглобін, еритроцити, лейкоцити, екстенсивність інвазії, Дніпро-Бузький лиман, Миколаӥвська та Одеська області.

\section{Вступ}

Паразити є однією з важливих ланок у ланцюзі гідробіоценозів. Оскільки риба може виступати у ролі як дефінітивного, проміжного та додаткового хазяїна гельмінтів, - статевозрілі та личинкові стадії останніх інвазують промислові види риб, птахів, ссавців, а також людину.

Відомо, що найбільш тісні взаємини паразитів 3 хазяями бувають тоді, коли ті оселяються безпосередньо у їхніх тканинах. У таких випадках найбільш гостро відчувається негативний вплив паразитів на гомеостаз організму хазяїна через механічні пошкодження тканин, порушення обмінних процесів та роботи імунної системи, що нерідко супроводжуються важкими клінічними проявами та високою летальністю (Bikhovskaya-Pavlovskaya, 1985).

Нематода Eustrongylides excisus належить до родини Dioctophymatidae та становлять потенційну загрозу здоров'ю людини (Deardorff \& Overstreet, 1991; Ljubojevica, 2015). Вид був обгрунтований Егершельдом у 1909 році в результаті вивчення нематод, виявлених в залозистому шлунку бакланів (Karmanova, 1968). Згідно з аналізом видового складу інвазованих риб встановлено, що найбільш ураженим виявився окунь, екстенсивність інвазії була - 85,1\%.

У водоймах України нематода E. excisus зареєстрована на різних ділянках Запорізького водосховища в окуня (P. fluviatilis), екстенсивність інвазії становила $-65 \%$, інтенсивність інвазії була до 68 паразитів в одній рибі. Також еустронгілідоз виявляли у сома річкового ( $S$. glanis), екстенсивність інвазії - 12\%, судак (S. lucioperca) був також уражений личинками нематоди E. excisus 3 показниками інвазії $25 \%$, інтенсивність інвазії - 1-6 екземплярів. Водночас (Sidorenko, 2016) повідомляє, що в Запорізькому водосховищі окунь уражений еустронгілідозом на 72\%, а окремі його популяції і до 100\%. Також цей вид гельмінтів відмічено у бичкових риб Чорного та Азовського морів (Korniychuk et al., 2008).

Серед хижих риб акваторій Дніпро-Бузького лиману та дельти Дніпра екстенсивність інвазії у судака складала $-58,1 \%$, а у щуки - 58,9\%. В окуня показники амплітуди інтенсивності інвазії були - 1-14 паразитів. Судак відзначався найменшими показниками інтенсивності інвазії серед досліджуваних хижих риб - 1-9 личинок нематоди E. excisus. Середній показник екстенсивності інвазії у досліджуваних водоймах
Миколаївської та Херсонської областей був 70,5\% (Goncharov et al., 2018).

Даний вид широко поширений у світі. Про реєстрацію E. excisus повідомлено у Сербії, Румуніїі, Турції, Бразилії, США, Італії, Ірані, Азербайджані,Чехії, Pociї, а також Україні (Goga \& Codreanu-Balcescu, 2013; Fedorov et al., 2014; Noei et al., 2015; Branciari et al., 2016; Demir \& Karakişi, 2016).

За еустронгілідозу хижих риб не досліджено у повній мірі патогенез та не відомо, як паразит впливає на морфологічні показники крові за цієї інвазії.

Метою даної роботи було провести гематологічні дослідження крові риб, інвазованих личинками нематод E. Excisus, та встановити, як паразитування цієї нематоди в організмі проміжного хазяїна - хижих риб впливає на морфологічні показники крові останнього.

\section{Матеріал і методи досліджень}

Упродовж 2014-2018 років клініко-лабораторному дослідженню було піддано 981 екземплярів трьох видів хижих риба, а саме: окуня - 481 екз., судака 203 екз. та щуки - 297 екз. Відбирали рибу під час проведення планових контрольних обловів, виловлювали її вудочками, а також купляли у рибалок на місці вилову. Відбір зразків риби проводили вздовж берегової лінії Дніпро-Бузького лиману та дельти Дніпра, в адміністративних межах Миколаївської області (поблизу села Дніпровське Очаківського району та мису Аджігол) та у частині акваторії, що адміністративно розташована в Херсонській області (поблизу сіл Олександрівка, Станіслав та Софіївка Білозерського району; поблизу сіл Рибальче та Геройське Голопристанського району).

Визначення морфологічних показників крові проводили у 25 інвазованих збудником еустронгілідозу та 25 вільних від цієї інвазї риб кожного виду, а саме окуня, щуки та судака. Риба, що піддавалась дослідженню, була статевозрілою, переважно вікових категорій $3+-5+$. Вік риби визначали за отолітами. Для дослідження кров відбиралась на місці вилову риби із серця за допомогою голки та шприца. На місці відбору готували мазки і просушували їх на повітрі. 3 метою проведення морфологічних досліджень крові хижих риб обиралися відповідні методики для цих випробувань. 


\section{Результати та їх обговорення}

Кров $є$ унікальною тканиною та системою, що виконує ряд надзвичайно важливих функцій: транспортну, тканинний газообмін, підтримання сталості життєвих показників тощо. Однією $з$ важливих функцій крові риб, яку важко переоцінити, є захисна, що спрямована на захист внутрішнього середовища організму гідробіонтів від чужорідних для нього об'єктів (паразитів, бактерій, вірусів та грибів. Саме тому дослідження гематологічних показників дає уявлення про стан організму риб в конкретних умовах існування під впливом різноманітних екзогенних факторів, таких як паразити.

Під час проведення морфологічних досліджень крові окунів, які були інвазовані личинками нематоди E. Excisus, було встановлено, що вміст гемоглобіну знижувалися на $6,87 \%(\mathrm{P}<0,05)$, тобто на 5,5 г/л порівняно $з$ контрольною групою риб. Кількість еритроцитів у крові заражених окунів також зазнавала змін порівняно з окунями, вільними від цієї інвазії та вірогідно зменшувалась на 0,8 Т/л, а саме на 42,11\% $(\mathrm{P}<0,05)$.

Встановлено, що за кількістю лейкоцитів крові окуня здорові риби відрізнялися від інвазованих нематодами E. excisus і їхній рівень збільшувався у хворих риб. Так, у дослідній групі риб кількість лейкоцитів збільшувалась на 3,5 Г/л, що було на $8,95 \%$ $(\mathrm{P}<0,05)$ більше, ніж у контрольної групи риб.

Лейкоцитарна формула $є$ чутливим індикатором фізіологічного стану організму риб, що швидко і показово реагує на зміни навколишнього середовища. Саме тому відсоткове співвідношення лейкоцитів яскраво відображає стан клітинної складової неспецифічного імунітету. Аналізуючи показники лейкоцитарної формули, було встановлено що кількість псевдобазофілів та базофілів значно зростала за еустронгілідозу, а саме на 129,17\% (Р < 0,01) у дослідній групі окунів, порівняно з контрольною. Показники псевдоеозинофілів та еозинофілів також змінювалися. Так, у хворих на еустронгілідоз окунів відмічали збільшення кількості цих популяцій лейкоцитів на 131\% ( $<<0,01)$ порівняно із неінвазованими окунями. Співвідношення нейтрофільних гранулоцитів зазнавало істотних змін в різних досліджуваних групах риб. При проведенні гематологічних досліджень крові окунів юних нейтрофілів не відмічали. Кількість паличкоядерних та сегментоядерних нейтрофілів у крові дослідної групи риб значно збільшувалась, а саме на 27,92 і $37,5 \%(\mathrm{P}<0,05)$ відповідно - порівняно 3 контрольною групою риб.

Кров окунів, власне як і інших досліджуваних видів риб: щуки та судака, має лімфоцитарний профіль. Така класова типізація відображає еволюційну недосконалість риб як хребетних, та дає чітке уявлення про специфіку факторів захисту на “еволюційному щаблі" розвитку живих істот.

Кількість лімфоцитів у крові дослідної групи риб зменшувалась на $3,27 \%(\mathrm{P}<0,01)$ порівняно 3 контрольною групою окунів. Доля моноцитів у переферійній крові інвазованих личинками нематоди окунів вірогідно збільшувалась на $16,34 \%(\mathrm{P}<0,05)$ порівняно 3 такими, що не були вільними від збудника еустронгілідозу (табл.1).

\section{Таблиця 1}

Морфологічні показники крові окуня за еустронгілідозу, $\mathrm{n}=50, \mathrm{M} \pm \mathrm{m}$

\begin{tabular}{|c|c|c|}
\hline \multirow{2}{*}{ Показники } & \multicolumn{2}{|c|}{ Групи риб } \\
\hline & контрольна & дослідна \\
\hline Гемоглобін, г/л & $80,1 \pm 0,87$ & $74,6 \pm 1,14^{*}$ \\
\hline Еритроцити, Т/л & $1,9 \pm 0,26$ & $1,1 \pm 0,11^{*}$ \\
\hline $\begin{array}{l}\text { Лейкоцити, Г/л } \\
\text { Лейкограма, \% }\end{array}$ & $39,1 \pm 1,87$ & $42,6 \pm 1,5^{*}$ \\
\hline $\begin{array}{l}\text { Псевдобазофіли, } \\
\text { базофіли }\end{array}$ & $0,48 \pm 0,12$ & $1,1 \pm 0,21 * *$ \\
\hline $\begin{array}{l}\text { Псевдоеозинофіли, } \\
\text { еозинофіли }\end{array}$ & $0,39 \pm 0,07$ & $0,9 \pm 0,36^{* *}$ \\
\hline $\begin{array}{l}\text { Нейтрофіли: } \\
\text { юні }\end{array}$ & - & - \\
\hline паличкоядерні & $2,4 \pm 0,87$ & $3,07 \pm 0,54^{*}$ \\
\hline сегментоядерні & $1,6 \pm 0,59$ & $2,2 \pm 0,62 *$ \\
\hline Лімфоцити & $91,52 \pm 2,87$ & $88,53 \pm 0,98 * *$ \\
\hline Моноцити & $3,61 \pm 0,47$ & $4,2 \pm 0,98^{*}$ \\
\hline
\end{tabular}

Морфологічними дослідженнями периферійної крові щук було виявлено, що рівень вмісту гемоглобіну в дослідної групи риб знижувався на 8,5 г/л порівняно $з$ контрольною групою, що у відсотковому відношенні становило зниження вмісту гемоглобіну на $11,02 \%$ (P < 0,05). Кількість еритроцитів у групі щук, що були уражені личинковою стадією нематоди E. excisus, знижувалась на 0,5 Т/л порівняно з особинами, що були вільними від цієї інвазії, тобто на 26,32\% (P < 0,05). Загальна кількість лейкоцитів у дослідній групі риб мала тенденцію до збільшення на $22,02 \%(\mathrm{P}<0,05)$ порівняно 3 контрольною групою риб, тобто на 8,5 Г/л. Серед особин риб найбільша кількість псевдобазофілів та базофілів реєструвалась у дослідній групі щук, порівняно з рибами, що не були інвазовані збудником еустронгілідозу. Так, збільшення цієї популяції гранулоцитарних лейкоцитів у цих досліджуваних групах складало на 114\% ( $<<0,01)$. Кількість псевдоеозинофілів та еозинофілів також значно збільшувалась у щук дослідної групи на 95,83\% (P $<0,01)$ порівняно з особинами контрольної групи. Під час аналізування динаміки змін нейтрофільних гранулоцитів відмічали появу юних форм цих клітин білої крові (без розподілення їх на субпопуляції поліпотентного ряду). Так, було відмічено зменшення кількості юних нейрофілів у крові дослідної групи риб на 26\% (P < 0,01) порівняно з контрольною групою досліджуваного виду риб. Дослідженнями було відмічено збільшення паличко - та сегментоядерних нейтрофілів у крові заражених збудником еустронгілідозу щук на 1,71 та $46,72 \%(\mathrm{P}<0,05)$ відповідно - порівняно з вільними від цих гельмінтів риб (табл. 2). 


\section{Таблиця 2}

Морфологічні показники крові щуки за еустронгілідо3y, $\mathrm{n}=50 \mathrm{M} \pm \mathrm{m}$

\begin{tabular}{lrr}
\hline \multirow{2}{*}{ Показники } & \multicolumn{2}{c}{ Групи риб } \\
\cline { 2 - 3 } & контрольна & \multicolumn{1}{c}{ дослідна } \\
\hline Гемоглобін, Г/л & $77,1 \pm 1,87$ & $68,6 \pm 1,14^{*}$ \\
Еритроцити, Т/л & $1,9 \pm 0,12$ & $1,4 \pm 0,23^{*}$ \\
Лейкоцити, Г/л & $38,6 \pm 1,09$ & $47,1 \pm 2,41^{*}$ \\
Лейкограма, \% & & \\
Псевдобазофіли, & $0,5 \pm 0,08$ & $1,07 \pm 0,21^{* *}$ \\
базофіли & & \\
Псевдоеозинофіли, & $0,48 \pm 0,11$ & $0,94 \pm 0,17^{* *}$ \\
еозинофіли & & \\
Нейтрофіли: & $1,00 \pm 0,24$ & $0,74 \pm 0,11^{*}$ \\
юні & $3,5 \pm 0,47$ & $3,56 \pm 0,53^{*}$ \\
паличкоядерні & $2,59 \pm 0,27$ & $3,8 \pm 0,41^{*}$ \\
сегментоядерні & $88,91 \pm 3,19$ & $86,09 \pm 4,29^{* *}$ \\
Лімфоцити & $3,02 \pm 0,6$ & $3,8 \pm 0,25^{*}$ \\
Моноцити & \\
Примітка: ${ }^{*}-\mathrm{P}<0,05 ; * *-\mathrm{P}<0,01$ порівняно 3 контроль- \\
ною групою.
\end{tabular}

Під час морфологічних досліджень крові риб дослідної групи було відмічено зменшення кількості лімфоцитів порівняно з контрольною групою риб на $3,16 \%$ ( $<0,01)$, однак така різниця, на нашу думку, $\epsilon$ статистично незначною. Моноцити переферійної крові переважали за кількістю у щук, які були інвазовані личинками нематоди E. excisus, на 25,83\% (P < 0,05), порівняно з рибами, що були вільними від цієї інвазії.

Морфологічними дослідженнями крові судака було встановлено незначне зниження вмісту гемоглобіну в крові риб дослідної групи, а саме на 4,73 г/л порівняно 3 контрольною групою риб, тобто на 6,3\% $(\mathrm{P}<0,05)$. Кількість еритроцитів також знижувалась у корові уражених збудником еустронгілідозу судаків на 0,55 Т/л порівняно з судаками, що не були ураженими цією інвазією. Так, кількість еритроцитів знижувалась в дослідній групі на 30,05\% (P < 0,05). При визначенні загальної кількості лейкоцитів у дослідній групі судаків, було встановлено збільшенні їхньої кількості на 4,3 Г/л, а саме на 10,6\% (P < 0,05) порівняно 3 контрольною групою риб. При аналізуванні показників лейкоцитарної формули було виявлено, що у крові судаків інвазованих личинками нематоди E. excisus кількість псевдобазофілів та базофілів збільшувалась на 69,23\% (P < 0,01) порівняно з судаками, які були вільними від цього паразита. Кількісні показники рівня псевдоеозинофілів та еозинофілів у крові дослідної та контрольної групи риб також різнилися. Так, кількість цих клітин білої крові значно збільшувалась у дослідної групи риб та становила на $116,67 \%$ (P < 0,01) більше, ніж у крові судаків контрольної групи. Аналізуючи показники рівня нейтрофільних гранулоцитів, було виявлено збільшення кількості юних нейрофілів у досліджуваній групі судаків, які були уражені збудником еустронгілідозу на $5,75 \%(\mathrm{P}<0,05)$ порівняно 3 контрольною групою риб. Кількість паличко- та сегментоядерних нейтрофільних гранулоцитів також зазнавала значних змін у крові заражених нематодозною інвазією риб. Так, у крові дослідної групи відмічали збільшення зазначених лейкоцитів на 15,58 та 23,27\% (P < 0,05) відповідно - порівняно 3 контрольною групою судаків. Показники лімфоцитів у групі риб, що була заражена збудником еустронгілідозу знижувалися на 4,4\% (Р < 0,01) порівняно зі здоровою рибою, що є статистично незначним при зазначених показниках відсоткового співвідношення лейкоцитарної формули. Варто зазначити, що кількість лімфоцитів у судаків контрольної групи була однією з найменших серед інших досліджуваних видів хижих риб: окуня та щуки. Кількість моноцитів у дослідної групи риб збільшувалась на $17,46 \%(\mathrm{P}<0,05)$ порівняно 3 контрольною групою судаків (табл. 3).

\section{Таблиця 3}

Морфологічні показники крові судака за еустронгілідозу, $\mathrm{n}=50, \mathrm{M} \pm \mathrm{m}$

\begin{tabular}{lrc}
\hline \multirow{2}{*}{ Показники } & \multicolumn{2}{c}{ Групи риб } \\
\cline { 2 - 3 } Контрольна & дослідна \\
\hline Гемоглобін, Г/л & $75,03 \pm 2,23$ & $70,3 \pm 1,52^{*}$ \\
Еритроцити, Т/л & $1,83 \pm 0,07$ & $1,28 \pm 0,13^{*}$ \\
Лейкоцити, Г/л & $40,6 \pm 1,19$ & $44,9 \pm 1,14^{*}$ \\
Лейкограма, \% & & \\
Псевдобазофіли, & $0,52 \pm 0,17$ & $0,88 \pm 0,02^{* *}$ \\
базофіли & & \\
Псевдоеозинофіли, & $0,42 \pm 0,17$ & $0,91 \pm 0,11^{* *}$ \\
еозинофіли & & \\
Нейтрофіли: & & \\
юні & $0,87 \pm 0,21$ & $0,92 \pm 0,17^{*}$ \\
паличкоядерні & $5,2 \pm 2,87$ & $6,01 \pm 2,19^{*}$ \\
сегментоядерні & $5,93 \pm 1,27$ & $7,31 \pm 0,89^{*}$ \\
Лімфоцити & $83,68 \pm 3,19$ & $80 \pm 2,51^{* *}$ \\
Моноцити & $3,38 \pm 0,72$ & $3,97 \pm 0,87^{*}$ \\
\hline Примітка: $*$ - Р $<0,05 ; * *-\mathrm{P}<0,01$ порівняно з контроль- \\
ною групою.
\end{tabular}

За результатами досліджень встановлено, що ураження хижих риб збудником еустронгілідозу призводить до зниження вмісту гемоглобіну та еритроцитів. Вочевидь, продукти життєдіяльності паразита, що потрапляють до організму риб, негативно впливають на процес еритропоезу, що призводить до зменшення кількість еритроцитів крові. Зниження вмісту гемоглобіну крові негативно впливає на процеси тканинного дихання та в подальшому - на окисно-відновні та обмінні процеси в організмі тощо.

Механічне пошкодження тканин, яке виникає внаслідок міграції паразитів в тканинах риб, призводять до виникнення локальних запальних процесів, створюються умови для проникнення вторинної мікрофлори до тканин внутрішнього середовища, що значно поглиблює патологічний процес. Захисним елементом організму та ключовою ланкою клітинного імунітету $\epsilon$ лейкоцити. Підвищення загальної кількості лейкоцитів свідчить про виникнення значних запальних процесів в організмі риб внаслідок патологічного впливу, що спричинений личинками нематоди E. excisus.

Значне підвищення кількості псевдоеозинофілів і еозинофілів, а також псевдобазофілів та базофілів 
свідчить про алергізуючий вплив паразита на організм хазяїна за рахунок виділення продуктів власного метаболізму гельмінтами.

Кількість нейтрофільних гранулоцитів також відображала вплив личинок паразита на організм риб. Так, юні нейтрофіли були зареєстровані у щуки та судака. У окуня ця субпопуляція клітин крові не була встановлена. Цікаво відмітити, що кількість юних нейтрофілів у щук дослідної групи зменшувалась порівняно 3 контрольною групою риб. Ймовірно, це вказує на те, що продукти метаболізму та життєдіяльності паразита інгібують функцію органів гранулоцитопоезу щук. У судака, навпаки, кількість юних нейтрофілів у дослідній групі риб збільшувалась порівняно з групою судаків, що не були інвазовані збудником еустронгілідозу. Вочевидь, продукти метаболізму, подразнюючи органи гранулоцитопоезу, не пригнічують їх функцію, а навпаки, стимулюють до посиленого синтезу незрілих нейтрофільних клітин 3 метою підвищення протективної здатності організму хазяїна. Дані результати досліджень свідчать про видову чутливість судака до паразитування личинок нематоди E. excisus.

Підвищення рівня кількості паличко- та сегментоядерних нейтрофільних гранулоцитів у крові хижих видів риб логічно відображає реакцію організму на запальний процес, що виникає внаслідок паразитування личинок гельмінта у тканинах хазяїна.

Кількість лімфоцитів крові всіх досліджуваних видів риб незначно знижувалась. Оскільки лімфоцити не володіють фагоцитуючими функціями, вони у формі тканинних макрофагів мігрують 3 периферійної крові до тканин та місць запальних процесів, таким чином знижуючи їх кількість у крові. Продукти метаболізму паразита також активно впливають й на органи імунопоезу риб - інгібують їхню функціональну активність і пригнічують лімфоцитопоез та наступну диференціацію цієї популяції клітин. Показники кількості моноцитів крові хижих риб за еустронгілідозу характеризувалися підвищенням останніх. Даний процес пов'язаний із функціями, що виконують моноцити: вони активно беруть участь у фагоцитозі в місцях запалення, виконують детоксикуючу функцію - здатні адсорбувати та нейтралізувати продукти метаболізму паразитів, а також запальних процесів.

\section{Висновки}

Узагальнюючи отримані результати гематологічних досліджень крові трьох видів досліджуваних видів риб, а саме окуня, щуки та судака, які були інвазовані збудником еустронгілідозу, можна дійти висновку, що даний паразит значно впливає на морфологічні показники крові цих риб. За еустронгілідозу в крові риб відмічено анемічні явища, еритропенію, загальний лейкоцитоз, а також значні коливання показників лейкоцитарної формули порівняно з рибами, що не були уражені цим збудником. Велику зацікавленість викликає коливання юних нейтрофілів у крові досліджуваних риб: відсутність останніх у гематологічному профілі окунів, підвищення їх кількості у щук та зниження у судаків. Отримані результати лабораторних досліджень вказують на те, що продукти життєдіяльності паразита значно впливають на процеси гранулоцитопоезу. Також, варто зазначити, що показники крові риб за еустронгілідозу характеризувалися підвищенням кількості паличко- та сегментоядерних нейтрофілів, а також незначним моноцитозом як результатом запальних явищ в організмі риб. Кількість лімфоцитів у крові всіх досліджуваних видів риб знижувалась.

\section{References}

Bikhovskaya-Pavlovskaya, I.E. (1985). Parasitesof fish: Study Guide. Nauka, Leningrad, 1- 121 (in Russian).

Branciari, R., Ranucci, D., Miraglia, D., Valiani, A., Veronesi, F., \& Urbani, E. (2016). Occurrence of parasites of the genus Eustrongylides spp. (Nematoda: Dioctophymatidae) in fish caught in Trasimeno lake, Italy. Italian Jour. of Food Safety, 5(4), 206-209. doi: 10.4081/ijfs.2016.6130.

Deardorff, T.L., \& Overstreet, R.M., (1991). Seafoodtransmitted zoonoses in the United States the fishes, the dishes, and the worms. In Microbiology of Marine Food Products. Microbiology of Marine Food Products, 211-265. doi: 10.1007/978-1-4615-3926-1_9.

Demir, S., \& Karakişi, H. (2016). Metazoan Parasite Fauna of the Prussian carp, Carassius gibelio (Bloch, 1782) (Cyprinidae), from Marmara Lake, Turkey. Acta zool. bulg. 68(2), 265-268. http://www.actazoologica-bulgarica.eu/downloads/acta-zoologicabulgarica/2016/68-2-265-268.pdf.

Fedorov, N.M., Firsov, N.F., \& Soloviev, N.A. (2014). Veterinary and sanitary examination in river perch with Eustrongylidosis. Veterinary pathology, 3(4), 6873. https://elibrary.ru/item.asp?id=23162375 (in Russian).

Goga, I.C., \& Codreanu-Balcescu, D. (2013). Preliminary records on the presence of the nematode Eustrongylides excisus at the fish species Silurus glanis and Perca fluviatilis from Victoria like (Bratovoieuti - Dolj). Oltenia. Studii úi comunicări. ùtiinĠele Naturii, 29(2), 184-190. http://biozoojournals.ro/oscsn/cont/29_2/ 26_Goga.pdf.

Goncharov, S., Soroka, N., Pashkevich, I., \& Dubovyi, A. (2018). Infection of predatory fish with nematodes Eustrongylides excisus, Jägerskiöld, 1909 - larvae (Nematoda: Dioctophymatidae) in the delta of the Dnipro river and Dnipro-Buh estuary in Southern Ukraine, Vestnik zoologii, 52(2), 137-144. doi: 10.2478/vzoo-2018-0015.

Karmanova, E.M. (1968). Dioctophymidea of Animals and Man and the Diseases Caused by Them. Nauka Publishing. Moscow (in Russian).

Korniychuk, Y.M., Pronkina, N.V., \& Belofastova, I P. (2008). Nematode Fauna of the round goby Apollonia (Neogobius) melanostomus in the Black Sea and Sea of Azov. Ecology of the sea, 17-22 (in Russian).

Ljubojevica, D., Novakov, N., Djordjevicc V., Radosavljevicd, V. \& Pelica, M. (2015). Potential parasitic 
hazards for humans in fish meat. Procedia Food Science, 5, 172-175. doi: 10.1016/j.profoo.2015.09.049.

Noei, M.R., Ibrahimov, S., \& Sattari, M. (2015). Parasitic worms of the Persian sturgeon, Acipenser persicus Borodin, 1897 from the southwestern shores of the Caspian Sea. Iranian Jour. of Ichthyology, 2(4), 287-295.
http://www.ijichthyol.org/index.php/iji/article/viewFile/ 107/84.

Sidorenko, V.S. (2016). Information on fish contamination with experimental helminths of the genus $\mathrm{Eu}-$ strongylides. Materials of the VIII Interstate Student Scient. Conf. Gorki. UO BGSHA, 202-208 (in Russian). 